\title{
Article
}

\section{Transnationalism and Social Work Education}

\author{
Cox, Pat
}

Available at http://clok.uclan.ac.uk/12700/

Cox, Pat ORCID: 0000-0003-2565-4564 (2015) Transnationalism and Social Work Education. Transnational Social Review, 5 (3). ISSN 2193-1674

It is advisable to refer to the publisher's version if you intend to cite from the work. http://dx.doi.org/10.1080/21931674.2015.1094973

For more information about UCLan's research in this area go to http://www.uclan.ac.uk/researchgroups/ and search for <name of research Group>.

For information about Research generally at UCLan please go to http://www.uclan.ac.uk/research/

All outputs in CLoK are protected by Intellectual Property Rights law, including Copyright law. Copyright, IPR and Moral Rights for the works on this site are retained by the individual authors and/or other copyright owners. Terms and conditions for use of this material are defined in the policies page.

\section{CLoK}

Central Lancashire online Knowledge www.clok.uclan.ac.uk

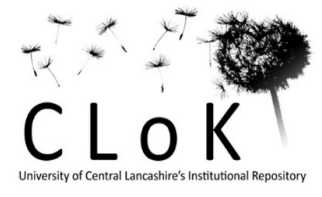




\section{Title: Transnationalism and Social Work Education.}

Author: Pat Cox, Reader in Social Work and Social Justice.

Correspondence details: pcox2@uclan.ac.uk

School of Social Work, University of Central Lancashire, Preston, PR1 2HE UK

Keywords: Transnationalism; social work education; migration.

\section{Introduction}

Transnational movements, networks and relationships are everywhere in this "world on the move” (Williams \& Graham, 2014, p.i1). Transnational peoples maintain relationships of interdependence and support with families and communities in their places of origin; often returning regularly, while making new lives and connections. Transnationalism is characterized by mobilities and networks; by social integration; by extended and extensive relationship ties of family, neighbourhood, religious faith or combinations thereof (Valtonen, 2008). While disciplines across the world including sociology, human geography and cultural anthropology engage with the implications of transnationalism (Bauböck \& Faist, 2010), social work in England and mainland Europe has not achieved similar levels of engagement. As Cox and Geisen state: “...the social world is being transformed by migration and social work is playing catch-up.” (2014, p. i162).

The consequences of transnational movements are experienced locally, nationally and internationally; transnationalism borders both private lives and public policies (Barberis \& Boccagni, 2014). Relationships, networks, social integration and social justice are among social work’s core concerns; the short and longer-term effects of transnationalism on relationships and on the social, institutional and political structures of social work's contexts should be core concerns as well (An \& Köngeter, 2013). 
In this paper the author had intended to examine weaknesses in the current model of English social work education, arguing that it does not address transnationalism. Following this critique she intended to develop academic and practice curricula which centralize transnationalism. However, between submitting this paper (mid-June 2015) and revising it for publication (mid-July 2015), the English government decreed that The College of Social Work (whose guidance documents underpin English social work education at present), was to close (Brindle, 2015). At mid-July, the future of English social work education is unclear; for the moment many qualifying courses continue delivering curricula informed by College of Social Work guidances. Despite this bouleversement, the author remains intent upon examining weaknesses in what is still the current model, learning from errors and omissions. She then designs social work education for England with transnationalism as its overarching paradigm, highlighting some of the obstacles to achieving her design. She acknowledges the anglophone-centred nature of this paper and the dominance of English as a global language within social work and social work education. The relevance of language for transnational social work education is addressed further in the Discussion.

\section{Social work education in England: Background and Critique}

The global nature and impact of transnationalism (Castles et al, 2014), highlights its centrality for social work education and practice; transnationalism is a paradigm which forces re-thinking existing knowledge and praxes. Since 1989, social work education in England has undergone continuous reform (CCETSW, 1989), yet in the current iteration of social work education for England (TCSW, 2012a), business has been much as usual.

The College of Social Work (hereafter TCSW) was an independent body which assured standards for the profession in England. It produced guidance documents on compulsory 
subjects for qualifying education (TCSW, 2012a). Each document is between two and four pages, written in a format set by the College and available from the TCSW website. They have been used by English social work educators in developing curricula. Out of the eighteen guidance documents there are two which address 'Migration and Refugees' and 'International Social Work', with mention of 'migration' in documents entitled: 'Diversity and Oppression’; 'Communication Skills’ and 'Physical Health, Dementia and End of Life Care'. Documents reflect social work’s focus on refugee and asylum-seeking peoples (Cox \& Geisen, 2014). Although ‘International Social Work’ refers to ‘migration’ as a global issue, transnationalism is not mentioned. No criticism is intended here of the guidance writers, who appear limited by the imposed format of compulsory subject areas for English social work education within a framework decided by the College.

However, scope exists for: “...learning opportunities in relation to ...other 'emergent' user groups” (TCSW, 2012b. p.3) and practice placement guidances (TCSW 2012c; 2013) are more generally written. Currently, transnationalism is a lacuna in English social work. To address this lacuna, before asking what we want social workers to do, we must ask: what do they need to understand and to know?

\section{Beginning transnational social work education}

It is insufficient to insert the word 'transnationalism' into social work curricula and hope for informed transnational praxes. Transnationalism in social work education begins with qualifying students learning to think critically and analytically, challenging normative assumptions about transnational peoples. Developing students’ confidence in knowledge analysis and critique strengthens practice: social workers’ lack of knowledge about migration issues results in uncertainty in interventions (Masocha, 2014). 
Critical and analytical thinking must be applied also to social work values, which perfuse both education and practice. In Johnson and Yanca's (2010) categorization of values as ultimate, proximate and instrumental, social work promotes values which can be defined as 'ultimate'; that is, abstract and easily agreed by many. Promoting ultimate values in social work education (the 'what'), may result in overlooking the detailed 'how'; the specific means by which instrumental values are realized. Values must be interrogated continually for their relevance to the challenges of transnational social work (Jönsson, 2014).

The failure of English and English-influenced social work education to overturn established norms and ideologies about differences is subject to frequent critique: for example, Brydon (2012). To address such critiques, social work educators must disrupt dominant political ideologies: communities, societies and nations are comprised of the descendants of earlierarriving peoples and of recent arrivals (Cox \& Geisen, 2014). Social work itself is comprised of numerous transnational peoples and social work educators must share with students something of our own and our families' origins and histories, demonstrating the contributions of transnational peoples and their descendants, while encouraging students to explore and share their own. (In this globalizing world, many people are transnational or have transnational forebears: Kasinitz et al, 2008). Analysis of the relevance of Whiteness Studies for social work education (Jeyasingham, 2012a; 2012b) disrupts hegemonic ideologies about identities, assisting in moving students towards critically engaged transnational praxes.

\section{Transnational academic curricula}

Transnationalism must be integrated completely across academic curricula, including assessments, not ‘added in’ to one module: 'Transnationalism and...'. A stand-alone module is insufficient too; both permit marginalization. Cross-curricula integration reflects more 
fully the near-universal nature of transnational movements and their implications for social work. Transnationalism includes elements of both agency and structure; relationships and structures are being changed by transnational peoples in this interconnected world (Valtonen, 2008).

Incorporating knowledge about transnationalism from other disciplines (social development, human geography, world history, psychology) would also benefit the proposed academic curricula. Included also - but not limited to - are transnational movements as lived experiences and reasons for these movements, including: development-induced displacement; state failure; war; famine; pandemics; persecution and the hopes for better lives. Given the swift evolution of transnational movements, curricula must always have space to incorporate new learnings and for new theories to emerge.

\section{Transnational practice curricula}

The relatively non-specific placement guidance documents (TCSW 2012c; TCSW 2013) which address selection criteria for community-based placements and standards expected of students and practice educators, have facilitated integrating transnationalism into practice curricula, providing a baseline for transnational practice. Social work usually centralizes the needs of settled individuals, families and groups; however, considering Johnson \& Yanca’s (2010) 'instrumental values’ (the 'how’), services should be designed and delivered for transnational peoples who are settling temporarily or in processes of settling permanently. Students in partnership with transnational peoples and practice educators can undertake service design and adaptation. Glick Schiller et al (1995) emphasize the agency of transnational peoples; thus the agency of children, young people, their families (Righard, 2014) and adults and older adults (Bolzman, 2014) will underpin students’ practice in communities. Such forms of practice will assist students in responding to expectations that 
transnational peoples must assimilate into the prevailing culture, which is constantly selfrevising (Kasinitz et al, 2008). Many qualifying courses already arrange transnational practice placements, with valuable learnings for students: see Ashencaen Crabtree et al (2014).

\section{Discussion}

In contemporary transnational contexts, English and English-influenced social work knowledge and practice are not universally applicable (Zack-Williams, 2006). There are discussions about whether the recent International Federation of Social Workers \& International Association of Schools of Social Work (hereafter IFSW \& IASSW, 2014) global definition of social work is possible, or desirable; differences exist between nations concerning the responsibilities of professionally-educated social workers (Jönsson, 2014). Given the foregoing, how do we improve understandings and knowledge, moving to action for change where required, so that transnational social work education becomes the 'new normal'?

One answer is that English and English-influenced social work academic educators acknowledge that English social work's cultural hegemony is neither appropriate nor viable in transnational contexts. English and English-influenced social work academic educators must begin surrendering our positions as framers of social work knowledge; relinquishing such power will be perceived as difficult, but it is necessary action. Looking outwards for ideas and knowledge to other nations and languages (for example, Köngeter et al, 2015), and adopting them, would demonstrate capacity to learn.

A second answer addresses the dominance of English as a global social work academic language. The author proposes that unless already fluent in more than one language, English social work academic educators learn one or more languages, or re-learn languages studied 
previously. This proposal will be perceived as vexatious: many academic educators see ourselves as purveyors of knowledge - possibly being unwilling to learn languages, a field in which we did not or do not excel; and English monolingualism (British Academy, 2013) infects some academics. Despite these obstacles, such action - another 'how': Johnson \& Yanca (2010) - would displace English from academic dominance, leading to conference and journal papers presented and written in numerous languages, with greater inclusion of contributors. Concurrently, language learning also becomes a 'compulsory subject' for social work students, to prepare them more completely for transnational practice. One obstacle is that current academic curricula are deemed to be crowded (TCSW, 2012a); another is English monolingualism (British Academy, 2013). However, as with space for academics’ language learning, space for students' language learning must be made - these are among the 'hows' of transnational social work education.

A third answer addresses questions about how else social work academics might maintain and enact the profession's social justice imperative. Becoming public intellectuals (Oh, 2015); bringing counter-balancing information about transnationalism into public domains by writing in the press and speaking with groups and communities outside universities should be considered as possibilities. Confidentiality can be observed, if specific examples are avoided (Betts, 2015).

\section{Conclusion}

England is both a sending and a receiving transnational nation: transnationality intersects with 'race', ethnicities, gender, sexuality, nationality, age and class backgrounds (Crenshaw, 2015) and transnationalism must be at the centre of future curriculum design and delivery in English social work education. In another social work context, Mlcek (2014, p.1984) asks: 
“Are we doing enough?” In relation to transnationalism and social work education, this author replies: 'No; we need to work on it much more.'

\section{References}

An, S. \& Köngeter, S. (2013) Mapping transnationalism: Introduction. Transnational Social

Review: A Social Work Journal, 3, M26-M27. doi: 10.1080/21931674.2013.10920754

Ashencaen Crabtree, S., Parker, J., Azman, A. \& Carlo, D.P. (2014) Epiphanies and learning in a postcolonial Malaysian context: A preliminary evaluation of international social work placements. International Social Work, 57, 618-629. doi:10.1177/0020872812448491

Barberis, E. \& Boccagni, P. (2014) Blurred rights, local practices: Social work and immigration in Italy. British Journal of Social Work, 44, (Suppl. 1), pp i70-i87. doi:10.1093/bjsw/bcu041

Bauböck, R. \& Faist, T. (2010) (Eds) Diaspora and transnationalism: Concepts, theories and methods. Amsterdam: Amsterdam University Press.

Betts, A. (2015, April 26th) Forget the 'war on smuggling', we need to be helping refugees in need. The Observer, pp18-19. 
Bolzman, C. (2014) Older Refugees. In: E. Fiddian-Qasmiyeh, G. Loescher, K. Long \& S.

Nando (Eds) The Oxford handbook of refugee and forced migration studies (pp. 409-419).

Oxford: Oxford University Press.

Brindle, D. (2015, June $24^{\text {th }}$ ) The College is dead. Long live the College? The Guardian, p.37

British Academy (2013) Languages: The state of the nation. Demand and supply of language skills in the UK. London: British Academy.

Brydon, K. (2012) Promoting diversity or confirming hegemony? In search of new insights for social work. International Social Work, 55, 155-167. doi: 10.1177/002087281142587

Castles, S., de Haas, H. \& Miller, M. J. (5th ed.) (2014) The age of migration: International population movements in the modern world. Basingstoke: Palgrave Macmillan.

(CCETSW) Central Council for Education and Training in Social Work (1989) Requirements and regulations for the diploma in social work (Paper 30). London: CCETSW.

Cox, P. \& Geisen, T. (2014) Migration perspectives in social work research: Local, national and international contexts. British Journal of Social Work 44, (Suppl. 1), pp. i157-i173. doi:10.1093/bjsw/bcu044 
Crenshaw, K. W. (2015) On intersectionality: The essential writings of Kimberlé Crenshaw. New York, NY: The New Press.

Glick Schiller, N., Basch, L. \& Blanc, C.S. (1995) From immigrant to migrant: Theorizing transnational migration. Anthropological Quarterly, 68, 48-63.

(IFSW\&IASSW) International Federation of Social Workers \& International Association of Schools of Social Work (2014) Global definition of social work. Retrieved from http://www.ifsw.org/policies/definition-of-social-work/

Jeyasingham, D. (2012a) White noise: A critical evaluation of social work education's engagement with whiteness studies. British Journal of Social Work, 42, 669-686. doi:10.1093/bjsw/bcr110

Jeyasingham, D. (2012b) A clarification of 'white noise' and some observations about Paul Michael Garrett’s response. British Journal of Social Work, 42, 1416-1420. doi: 10.1093/bjsw/bcs158

Johnson, L. C. \& Yanca, S. J. (10 ${ }^{\text {th }}$ ed.) (2010) Social work practice: A generalist approach. New Jersey: Pearson Education. 
Jönsson, J. H. (2014) Local reactions to global problems: Undocumented immigrants and social work. British Journal of Social Work 44, (Suppl. 1), pp. i35-i52. doi:10.1093/bjsw/bcu042

Kasinitz, P., Mollenkopf, J. H., Waters, M. C. \& Holdaway, J. (2008) Inheriting the city: The children of immigrants coming of age. New York: Russell Sage Foundation.

Köngeter, S., Altissimo, A., Jakoby-Hertz , A. \& Schröer, W. (2015) Child and youth welfare in globalized societies: Migration in child and youth care: a transnational curriculum for social work courses. Transnational Social Review: A Social Work Journal. doi: $10.1080 / 21931674.997086$

Masocha, S. (2014) We do the best we can: Accounting practices in social work discourses of asylum seekers. British Journal of Social Work, 44, 1621-1636. doi: 10.1093/bjsw/bcto48.

Mlcek, S. (2014) Are we doing enough to promote cross-cultural competencies for social work? British Journal of Social Work, 44, 1984-2003. doi: 10.1093/bjsw/bct044

Oh, H. (2015) Publics, we need you! Social work researchers and educators as public sociologists. Social Work Education, 34, 125-129. doi.org/10.108002615479.2014.944145 
Righard, E. (2014) Families in context: A transnational approach. In S. Hessle (Ed) Global social transformation and social action: The role of social workers (pp. 131-136). Aldershot: Ashgate.

(TCSW) The College of Social Work (2012a) Curriculum Guides. Retrieved from

http://www.tcsw.org.uk/Curriculum-Guides/

(TCSW) The College of Social Work (2012b) Guidance for the application of the generic Professional Capabilities Framework (PCF) to ensure learning covers all ages and service user groups. Retrieved from https://www.tcsw.org.uk/uploadedFiles/TheCollege/Social_Work_Education/GuidanceProfes sionalCapabilitiesFramework(edref3).pdf

(TCSW) The College of Social Work (2012c) Practice Learning. Retrieved from https://www.tcsw.org,uk/uploadedFiles/TheCollege/Social_Work_Education/PracticeLearning(edref7).pdf

(TCSW) The College of Social Work (2013) Placement Criteria. Retrieved from https://www.tcsw.org,uk/uploadedFiles/TheCollege/Social_Work_Education/PlacementCriter ia(edref9)2013.pdf 
Valtonen, K. (2008) Social work and migration: Immigrant and refugee settlement and integration. Aldershot: Ashgate.

Williams, C. \& Graham, M. (2014) 'A world on the move’: Migration, mobilities and social work (Editorial). British Journal of Social Work 44, (Suppl. 1), pp. i1- i17. doi:

10.1093/bjsw/bcu058

Zack-Williams, T. B. (2006) Child soldiers in Sierra Leone and the problems of demobilisation, rehabilitation and reintegration into society: Some lessons for social workers in war-torn societies. Social Work Education, 25, pp. 119-128. doi:10.1080/02615470500487085

(Paper and references total 2,572 words). 